\title{
Hannah's Song: A Foreshadowing of the Magnificat
}

\author{
James W. Ellis
}

\section{ABSTRACT}

\begin{abstract}
Although women's words account for a small portion of biblical scripture, the Bible records two related prayerful songs that were sung by female prophets: the song of Hannah, in the Old Testament, and the Magnificat of Mary, in the New Testament. This essay uses typological methodology to explore the songs' connections, including their shared literary precedents and nearly identical theological themes. Their fundamental similarities suggest Hannah's song served as a harbinger of the Magnificat. Hannah and Mary's shared blessing, divinely ordained motherhood, and their shared inspiration, the Holy Spirit, explain the parallels of their prayerful verses and prophetic utterances, which were of great relevance for both covenants of the Judeo-Christian faith.
\end{abstract}

Keywords: Hannah, Hebrew Bible, Magnificat, Typology.
Published Online: June 16, 2021

ISSN: $2736-5514$

DOI: $10.24018 /$ theology.2021.1.3.14

\section{J. W. Ellis*}

Benjamin N. Cardozo School of Law, Yeshiva University, New York, USA. (e-mail:

james.ellis@alum.cardozo.yu.edu)

*Corresponding Author

\section{INTRODUCTION}

Women's words constitute a relatively tiny portion of biblical scripture. However, there are three important songs attributed to women recorded in the Bible, each reflecting profound faith and gratitude for God's mercy [1], [2]. They are the song of Hannah, recorded in First Samuel 2:1-10, Mary's Magnificat, found in Luke 1:46-55, and the lyrical verses of Deborah, in Judges 5:1-31. Deborah's verses are unique. Deborah was a powerful Judge ( $\breve{s} \bar{a} \bar{p} a t)$ of Israel and military leader. After guiding an Israelite army to victory over the Canaanites, Deborah sang an epic, victorious "war song," which was "shot through with genuine religious feeling" [3 p343]. Hannah and Mary's songs were quite dissimilar to Deborah's, yet quite similar to each other. Indeed, they are so similar theologians have suggested Hannah's song was a prophetic symbol pointing forward in time to Mary's song. The term prophesy encompasses foreknowledge of future events, awareness of past events of which there is no memory, or awareness of present hidden things that cannot be ascertained by human senses or reason [4]. Prophesy combines divinely revealed knowledge and a prophet's dissemination of that knowledge for the benefit of others [4].

This essay makes use of typological methodology to explore the connections between Hannah and Mary and their two songs. Although typology is a relatively recent nineteenth-century term, for many centuries biblical expositors have described people, things, and events found in the Hebrew Bible, or Old Testament, as prophetic "types" (or signals) of people, things, and events found later in the New Testament. Within the field of typology, there are generally two schools of thought [5]. One school insists the only reliable types are those explicitly recognized as such by a New Testament author; other clear correlations between Old Testament stories and the life of Christ are relegated to the status of mere illustrations or analogies. This school asserts the Holy Spirit inspired unambiguously identified types and anything else is simply the result of man's study [6].

Such reasoning seems to overlook key Bible passages. Jesus' disciples taught the "gift of the Holy Spirit" is given to "all whom the Lord our God will call" (Acts 2:38-39 NIV) and "all Scripture is God-breathed and is useful for teaching ... and training in righteousness, so that the servant of God may be thoroughly equipped for every good work" (2 Timothy 3:16-17). Early Christian theologians, including Clement (ca. 150-215) and Origen (ca. 184-253) of Alexandria, and Augustine of Hippo (354-430) effectively used allegorical interpretation of biblical narratives to discover deep spiritual truths in plain-sounding accounts. Augustine, for example, showed the many ways Noah's ark prefigured the Christian Church [7]. Modern Bible scholars, including the Scottish theologian Patrick Fairbairn (18051874), advocated accepting "both innate (explicit) and inferred (implied) types, and contended that many more correspondences [were accepted] in the New Testament period than happened to be enumerated in the texts themselves" [8], p. 698.

This all relates to the longstanding debate over the reliability and acceptability of "typological prophesy" versus "rectilinear prophesy." The exclusive rectilinear position holds that only spoken or written prophetic words that explicitly point to and describe only one person or event as a fulfillment are reliable. The typological view "describes a larger pattern and consistency about God's character, words, and actions" [9], pp. 3-4. Regarding much Old Testament prophesy, the typological expositor has the advantage of seeing from the standpoint of later biblical fulfillment Sometimes, an "Old Testament event is seen as a type only from the vantage point of the New Testament" [10], p. 123. This essay employs that vantage point. Inflexibly differentiating explicit Old Testament types from more subtle allegories can obscure the deep interrelation of biblical texts. The goal of this essay is to utilize a variety of interpretative 
strategies, including textual analysis, contextualization, and evangelical discourses to show why Hannah and her song could be understood as harbingers of Mary and the Magnificat.

\section{HANNAH AND HER SONG}

\section{A. Who Was Hannah?}

Hannah and her husband, Elkanah, lived during the eleventh century B.C. in Ramathaim (or Ramah), a village in the hill country of central Palestine inhabited by the Israelite tribe of Ephraim. Elkanah also had a second wife, named Peninnah. Hannah had no children, but Peninnah had many sons and daughters. Each year, Elkanah's family made a pilgrimage to the Tabernacle, the central religious sanctuary at Shiloh, to offer sacrifices during annual feasts, such as the Feast of Tabernacles. A priest named Eli presided over the sanctuary and sacrifices at Shiloh. The scriptures say that when Elkanah made his sacrifices, "he would give portions of the meat to his wife Peninnah and to all her sons and daughters. But to Hannah he gave a double portion because he loved her, and the Lord had closed her womb" (1 Samuel 1:4-5). Peninnah continually provoked and irritated Hannah because of her barrenness; until Hannah was so distraught, she wept and refused to eat.

On one of their annual trips to Shiloh, Hannah stood in the Tabernacle and prayed. Eli the priest watched her from a distance. Hannah prayed, "Lord Almighty, if you will only look on your servant's misery and remember me, and not forget your servant but give her a son, then I will give him to the Lord for all the days of his life, and no razor will ever be used on his head" (1 Samuel 1:11). The scriptures say that Hannah prayed "in her heart"; her lips moved but she did not speak aloud. Prayer may be "vocal or mental, private or public," and vocal forms of prayer may be sung as hymns or canticles [11]. Because of Hannah's seemingly odd behavior, moving her lips but making no sound, Eli thought she was intoxicated, and he said to her, “"'How long are you going to stay drunk? Put away your wine" (1 Samuel 1:14). Hannah denied she was intoxicated, and she explained to Eli, "I have not been drinking wine or beer; I was pouring out my soul to the Lord. Do not take your servant for a wicked woman; I have been praying here out of my great anguish and grief' (1 Samuel 1:15-16). Eli responded, "Go in peace, and may the God of Israel grant you what you have asked of him" (1 Samuel 1:17). Hannah and Elkanah returned to Ramathaim, and "the Lord [indeed] remembered" Hannah. She conceived and gave birth to a son, whom Hannah named Samuel because she had "asked the Lord for him" (1 Samuel 1:20). The name Samuel means, "heard by God" in Hebrew.

When Samuel was of sufficient age, Hannah brought the boy back to the Tabernacle in Shiloh. Hannah presented Samuel to Eli, and she told the priest, "Pardon me, my lord. As surely as you live, I am the woman who stood here beside you praying to the Lord. I prayed for this child, and the Lord has granted me what I asked of him. So now, I give him to the Lord. For his whole life he will be given over to the Lord" (1 Samuel 1:26-28) (fig. 1). After dedicating Samuel to a life of religious service, Hannah sang her celebrated prayerful song.

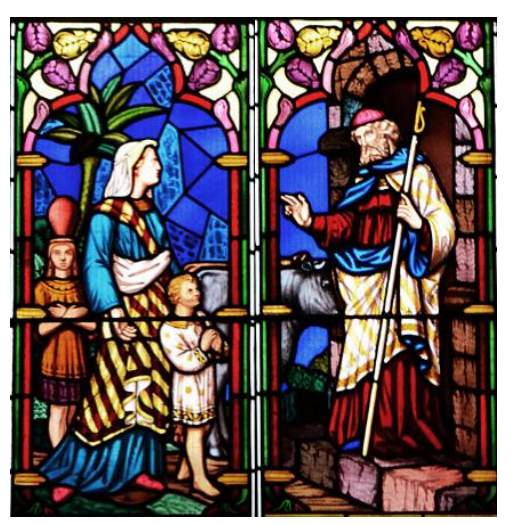

Fig. 1. William Wailes, A Mother in Israel: Hannah, Samuel and Eli, stained glass, 1862. Church of St. Mary the Virgin, Ambleside, U.K. Public Domain.

\section{B. Barrenness and Polygamy}

Before Samuel was conceived, the scriptures say, "the Lord had closed Hannah's womb." Hannah used the term "barren," meaning sterile (1 Samuel 2:5). The distress caused by barrenness and the value of giving life to a child are central themes in Hannah's narrative. In the ancient Near East, the status of motherhood conferred "a high degree of honor," and the inability to produce offspring was "felt as a stigma and deplored as a grievous calamity" [12]. Children were needed to help support their families and to carry on bloodlines. Hannah's barrenness was more than just a personal embarrassment; it was thought of as a physical defect or "disability" [13], and a family burden. There were also spiritual implications. The Hebrew Bible characterizes barrenness as a divinely withheld gift (Genesis 16:2), a punishment (Genesis 20:18), or even a curse (Hosea 9:11). Conversely, fertility is described as a blessing. The first chapter of the Bible says that after "God created the heavens and the earth," he "created mankind in his own image, in the image of God he created them; male and female he created them. God blessed them and said to them, 'Be fruitful and increase in number"' (Genesis 1:1, 27-28). Within this context, "be fruitful" clearly implies to prosper by having children.

Hannah and Elkanah were devout people of faith, and Hannah was probably aware that in the Hebrew Bible a woman's barrenness could "serve as a harbinger of the miraculous birth of a divinely chosen male leader" [14]. Three great matrons of ancient Israel-Sarah, Rebekah, and Rachel-were all described as initially barren (Genesis $11: 30 ; 25: 21 ; 29: 31)$, yet each went on to conceive a son who played a key role in the Hebrew age of patriarchs. Sarah and Abraham were the parents of Isaac. Rebekah and Isaac were the parents of Jacob. Isaac and Jacob carried on Abraham's bloodline, and they were crucial in the fulfillment of God's promise to Abraham that from his "offspring all nations on earth will be blessed" (Genesis 22:18). Christians believe that this promise was ultimately fulfilled by Jesus' birth (by Mary), and his life, death, and resurrection (Galatians 3:1314). According to biblical scholar Cynthia Chapman, in each of these biblical narratives, "barrenness serves a literary and theological purpose, heightening the tension around a divine promise of fertility and marking a child for divinely ordained leadership" [14]. Hannah and the birth of Samuel fit within this grand, historical series of events. 
Hannah was devout but she was also troubled, in part, because of her barrenness, and in part, because her family was divided by polygamy. The scriptures do not say so, but some have speculated that Hannah's barrenness may have been the reason Elkanah sought out another wife, Peninnah. According to the English Baptist prince of preachers Charles Spurgeon (1834-1892), polygamy was the "special cause of Hannah's sorrow." "Although it was tolerated under the old law, [polygamy] is always in practical action a most fruitful source of sorrow and sin" [15]. The Old and New Testaments make it clear that polygamy was not God's original intent for matrimony (Genesis 2:24; Matthew 19:4-6). The Bible records many instances when polygamous marriages did not go well (see, for example, Genesis 21 and 1 Kings 11). In the present case, Hannah was continuously and intentionally "provoked" and "irritated" by her "rival," and, despite Elkanah's efforts to sooth Hannah's misery, she retreated emotionally into melancholy and became "a woman of sorrowful spirit" [15].

Still, Hannah was a woman of faith, and she directed her emotions into prayers. The scriptures say, "In her deep anguish Hannah prayed to the Lord, weeping bitterly" (1 Samuel 1:10). This description is quite similar to the description of Jesus as he prayed and wept on the Mount of Olives on the night of his betrayal: "[B]eing in anguish, he prayed more earnestly, and his sweat was like drops of blood falling to the ground" (Luke 22:44). Hannah and Jesus' prayers were similar in another way. In both cases, personal requests were subordinated to the mission of God the father. Jesus prayed, "Father, if you are willing, take this cup from me; yet not my will, but yours be done" (Luke 22:42). Hannah prayed that if the "Lord Almighty [would] give her a son, then [she] will give him to the Lord for all the days of his life" (1 Samuel 1:11). Hannah did not want a son for her own benefit; she wanted a son to consecrate, or set aside, to serve God the father. Hannah's son would be similar to Mary' son, Jesus, who told his followers that he had "come down from heaven not to do my will but to do the will of [the father]" (John $6: 38)$.

\section{A Private Prayer of a Sorrowful Spirit}

Hannah prayed softly, inaudibly, perhaps silently, so no one else could hear. English nonconformist minister and Bible expositor, Matthew Henry (1662-1714) thought her quietness reflected both Hannah's awareness of God's omnipotence (unlimited power) and her own humbleness. By praying silently, she demonstrated "her belief of God's knowledge of the heart and its desires. Thoughts are words to him." He is not "one of those gods," like Baal, "that must be cried aloud to" (see 1 Kings 18:27) [16]. Hannah's quiet prayer was evidence of "her humility and holy shamefacedness in her approach to God." She avoided "all appearance of ostentation" and kept what passed between her soul and God to herself [16]. Ironically, the priest Eli misinterpreted Hannah's piety as insobriety. Eli's harsh censure ("Put away your wine.") was perhaps understandable though, and forgivable. Maybe Eli's eyesight had dimmed with age and maybe he had experienced intoxicated people in the Tabernacle previously, though such behavior defiled the sanctuary (Leviticus 10:8-10). Whatever the case, Eli soon realized his error and offered Hannah a kind benediction:
"May the God of Israel grant you what you have asked of him" (1 Samuel 1:17). Eli did not know it at that moment, but when God granted Hannah's wish and Samuel was born, Eli also received a wonderful blessing.

Rosh Hashanah (Hebrew for "beginning of [the] year") is a two-day New Year holiday designated in the Jewish calendar. Its origins are The Day of Trumpets (or Feast of Trumpets) established in Leviticus 23:23-25 and Numbers 29:1. Prayer and praying for God's blessings in the coming year are central to the observance. On the first day of Rosh Hashanah, rabbis read passages in the synagogues from the Hebrew Bible's Torah (the law) and Haftarah (the portion of the Bible containing the books of Samuel). It is tradition to read Genesis 21:1-34, which tells of the birth of Isaac to Abraham and Sarah, and 1 Samuel 1:1-2:10, which tells of the birth of Samuel and includes Hannah's prayer and song. Within Judaism (and Christianity), prayer takes on special meaning in times of suffering or times of crisis, when reliance on God's beneficence is even more evident. In times of suffering a person may offer a "crisis prayer" (or tefilah), asking God to remove a burden causing anguish. Hannah offered such a crisis prayer. Hannah's prayer was not selfish, though [17]. According to Rabbi Israel ben Eliezer (16981760) and others, when a godly person prays for what they want they are asking for what their soul wants and, since our souls are part of God, a godly person's prayer actually asks for what he wants [18], [19]. God wanted to bless Hannah and he wanted Samuel to be born.

Charles Spurgeon pointed out that before her child Samuel was born, Hannah was "a woman of sorrowful spirit," but "much that is precious may be connected with a sorrowful spirit" [15]. For example, Hannah's sorrow seemingly enhanced her prayer life. First, she prayed an intense private prayer, with urgency and an awareness of her dependence on God. Then, after God mercifully answered Hannah's prayer, with Samuel, she prayed an equally intense public prayer, which she sang as a hymn of praise. Theologian Matthew Henry wrote that praise for answered prayers is a moral obligation; it is "our rent, our tribute. We are unjust if we do not pay it" [16]. Hannah completed her "faith contract," and yielded her long-awaited son to God's service (as Mary would later also deliver her son, Jesus, for God's service). Hannah learned that when a person asks God for what they want most in life, they "relinquish [them]selves to God's will, allowing [their] identity to be composed as God determines it" [20].

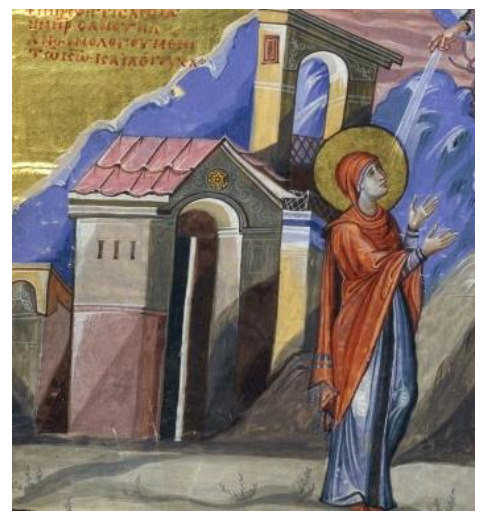

Fig. 2. "Hannah, Thanking God," manuscript illumination, Paris Psalter, ca. 950. Public Domain. 


\section{A Public Song of Praise, and Prophesy}

After dedicating Samuel to the Lord at the Tabernacle, Hannah celebrated by singing a public hymn (Fig. 2). Through the words of her song, Hannah became a powerful public witness of God's mercy and glory. When God later blessed Mary with the baby Jesus, she also celebrated with a hymn of praise, the Magnificat, through which she also testified openly of God's mercy and glory. The lyrics of the Magnificat evidenced Mary's "love of the Jewish scriptures," because Mary drew her themes and phrasings directly from the poetic verses of the Old Testament, from the Torah, the psalms, and the song of Hannah [21].

Here is the song of Hannah:

My heart rejoices in the Lord; in the Lord my horn is lifted high. My mouth boasts over my enemies, for I delight in your deliverance.

There is no one holy like the Lord; there is no one besides you; there is no Rock like our God.

Do not keep talking so proudly or let your mouth speak such arrogance, for the Lord is a God who knows, and by him deeds are weighed.

The bows of the warriors are broken, but those who stumbled are armed with strength. Those who were full hire themselves out for food, but those who were hungry are hungry no more.

She who was barren has borne seven children, but she who has had many sons pines away.

The Lord brings death and makes alive; he brings down to the grave and raises up.

The Lord sends poverty and wealth; he humbles and he exalts.

He raises the poor from the dust and lifts the needy from the ash heap; he seats them with princes

and has them inherit a throne of honor.

For the foundations of the earth are the Lord's; on them he has set the world.

He will guard the feet of his faithful servants, but the wicked will be silenced in the place of darkness.

It is not by strength that one prevails; those who oppose the Lord will be broken. The Most High will thunder from heaven; the Lord will judge the ends of the earth.

He will give strength to his king and exalt the horn of his anointed.

Hannah's hymn contains four primary themes: 1) the Lord's kindness and benevolence; 2) the Lord's authority over both the wicked and his "faithful servants"; 3) the Lord's eternal plan, including judgment of "the ends of the earth"; and 4) prophesy that the Lord will strengthen and exalt his anointed king.

Hannah began on a personal note. She rejoiced that the Lord interceded mercifully in her life and took away the source of her sorrow (her barrenness), by giving her a son. Hannah was not simply happy that she had a child, though, she felt blessed because the child was an answer to her prayer and a special gift from the Lord. She sang, "My heart rejoices ... I delight in your deliverance ... There is no one holy like the Lord ... [He] makes alive." Hannah called on others to humble themselves and to recognize the Lord's dominion over all earthly affairs. He will reward his servants, she sang, but silence the wicked "in the place of darkness." He shows benevolence toward his servants, bringing children to the barren and seating the poor in a "throne of honor," but he opposes the arrogant, breaking "the bows of the warrior" and making the well-fed hungry. As Mary will later reiterate, the Lord is "mindful of the humble state of his servant[s]."

The song builds in intensity, as it works its way toward a prophetic crescendo. Hannah moved beyond her personal circumstances to consider the broader "operation[s] of the Lord's hand." To use Patrick Fairbairn's words, Hannah "winged her flight aloft," and took an epic and "comprehensive survey of the general scheme of God," from Abraham in the past to "the dispensation of Christ" that lay ahead [22]. "The foundations of the earth are the Lord's," Hannah sang. He will reward the faithful and punish the wicked. From heaven, the Lord will "judge the ends of the earth" through the strength of his "anointed" king. To which anointed king did Hannah refer? When Hannah sang her song, Israel did not have an earthly king. She prophesized during the biblical era between Joshua's conquest of the "promised land" and the reign of King Saul, when Judges governed Israel (ca. 1200-1020 B.C.) [23]. Hannah's own son, Samuel, would be Israel's last Judge (1 Samuel 7:6). Therefore, Hannah had foreknowledge of future events and foreknowledge of a coming king.

Although soon after this prophesy, Israel would have earthly kings, their dominion and authority never extended to "the ends of the earth." Around 600 B.C., centuries after Hannah lived and at the end of the era of Israel and Judah's monarchs, the prophet Daniel proclaimed "the God of heaven will set up a kingdom that will never be destroyed [and will] endure forever" (Daniel 2:44). In the final book of the Bible, the Apostle John prophesized, "The kingdom of the world has become the kingdom of our Lord and of his Christ, and he will reign for ever and ever" (Revelation 11:15). These scriptures suggest that Hannah did not prophesize of the kings of Israel or Judah, but that she prophesized about the coming Messiah, Jesus Christ, whom the Apostles Paul and John called the "king of kings" (1 Timothy 6:15; Revelation 17:14 19:16).

This is the first time the Bible addresses the Messiah, the Lord's special anointed one. Anointed and Messiah are both

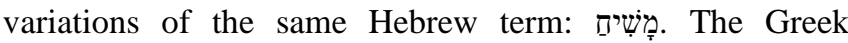
translation of this Hebrew term is Christos, from which comes the English word Christ. To anoint means to rub a person, place, or thing with oil to symbolize that person, place, or thing has been set aside or consecrated for divine use. The earthly kings of Israel, for example, were anointed 
with oil (1 Samuel 16:13; 2 Kings 9:6). Biblical expositor, Matthew Henry suggested Hannah's prophesy might have referenced both "the government of Israel by Samuel, and by [King] David whom he was employed to anoint" (1 Samuel 16), but also looked forward to "the kingdom of Christ" [16]. For Henry, Hannah purposefully adjoined the Lord's intention to eventually "judge the ends of the earth" with his intention to anoint the horn of his exalted king. This prophesy extended far beyond the Kingdom of Israel and beyond the reach of Samuel and King David. Hannah foresaw the coming of Jesus Christ and she knew the Lord would ensure "the subjects of Christ's kingdom will be safe, and the enemies of it will be ruined" [16].

Hannah also prophesized the Lord would "exalt the horn of his anointed" king. In the Bible, horns have various metaphorical meanings. They represent vigor, honor, and, because they are an animal's primary means of attack and defense, they represent power and dominion (see, for example, Deuteronomy 33:17; Job 16:15 [KJV]; Joshua 6:4$50)$. To have one's horn "exalted" was a sign of triumphant victory. For example, when John the Baptist was born, his father Zechariah sang joyously that the Lord had "raised up a horn of salvation for us," seemingly in reference to Jesus (Luke 1:69). The specific relevance of Hannah's “exalt the horn" prophesy will be explained in more detail a bit later.

\section{WOMEN's SONGS AND THE PSALMS}

Before moving on to a closer examination of the Magnificat, it is important to remember women's words, particularly women's songs, are very rare in the biblical scriptures. Given such rarity, it is reasonable that Bible scholars would search for (and perhaps perceive) deeper bonds uniting the songs of Hannah and Mary.

The Bible records three complete "victory psalms" sung by female prophets - those of Hannah, Deborah, and Maryand briefly references another, the song of Miriam (Exodus 15:21) [24], p.139. Another candidate for a female sacred song is Huldah's pronouncement in Second Chronicles 34:2328, which, like Hannah and Mary's songs, contains a statement of praise for God's mercy after a difficult incident and a reflective theological statement [2].

In total, the Bible contains nearly two hundred songs; the majority (150) are in the book of Psalms. Researchers debate how many of these may have been produced by women. Approximately half of the psalms have a preceding notation or superscription "of David" (לְדָוד), which is usually interpreted to mean "by David." Some scholars, however, are not convinced David wrote all of them. The Hebrew phrase "of David" may also be translated "to David," "in the style of David," "for David," or "about David." "Furthermore, the superscriptions that contain the phrase were probably written much later than the psalms themselves, making their attribution to David further suspect" [2]. Many of the psalms have superscriptions that do not name their potential authors, and more than twenty percent lack any superscription at all. Women may have written some of the anonymous psalms. In particular, researchers have sensed "a female hand" in the construction of Psalms 16, 113, and 131 [25], pp. 25-27.

Hannah's Song and Mary's Magnificat are thematically linked to the anonymously written Psalm 113. The psalm forms part of "the Egyptian Hallel" (Psalms 113-118), a set of hymns followers of Judaism sing or chant during the liturgy connected to the Jewish festivals of Passover (Pesach), Weeks (Shavuot), Tabernacles (Sukkot), Dedication (Hanukkah), and New Moon (Rosh Chodesh), but not during Rosh Hashanah or Yom Kippur. Hallel is a Hebrew term meaning "praise." Jews sing Psalm 113 specifically at the Passover meal, or Pesach Seder. The book of Psalms is in fact a collection of historical collections, and the various psalms range in date from the time of Moses (ca. 1450 B.C.) through the aftermath of the Babylonian exile (sixth century B.C.). Hannah was clearly familiar with Psalm 113 because she incorporated some of its language into her song verbatim.
He raises the poor from the dust and lifts the needy from the ash heap; he seats them with princes and has them inherit a throne of honor.

--1 Samuel 2:8.
He raises the poor from the dust and lifts the needy from the ash heap; he seats them with princes, with the princes of his people. --Psalm 113:7-8.
New Testament scriptures state Jesus and his Apostles sang together as a form of collective worship. The Gospels of Matthew and Mark tell the story of Jesus sharing the Passover feast with his disciples in Jerusalem, an occasion commonly known as "The Last Supper." Matthew and Mark wrote that after the feast, Jesus and his followers sang a hymn and then they went out of Jerusalem to the Mount of Olives (Matthew 26:30; Mark 14:26). If Jesus and his disciples were observing the traditional Pesach Seder, they probably sang from the Egyptian Hallel. If so, the event served as an important connection between the Jewish liturgy of singing psalms at Passover and the Christian liturgy of singing of psalms and hymns during the Eucharist, or Lord's Supper [26].

\section{MARY AND THE MAGNIFICAT}

\section{A. The Visitation}

In order to understand how Hannah's song was a shadow of Mary's Magnificat, it is vital to understand more about Mary's early life. It is a familiar story. The first chapter of the Gospel of Luke says that (ca. 5 B.C.) the angel Gabriel revealed to the elderly priest Zechariah and his wife Elizabeth that they would have a son and they should name him John [the Baptist]. The angel revealed their son would prepare the people "for the Lord" (Luke 1:17). A few months later, Gabriel appeared to Mary, a virgin living in Nazareth of Galilee. Gabriel told Mary "You will conceive and give birth to a son, and you are to call him Jesus. He will be great and will be called the Son of the Most High. The Lord God will give him the throne of his father David, and he will reign over Jacob's descendants forever; his kingdom will never end" (Luke 1:31-33). Gabriel told Mary her cousin Elizabeth would also have a child.

The Gospel of Luke says, Mary, who was already pregnant with Jesus, traveled from Nazareth to "a town in the hill country of Judea," perhaps Hebron [27], to visit Elizabeth (Luke 1:39-45). Christians call this episode "The Visitation.' When Mary entered Elizabeth's home, "the baby leaped in 
[Elizabeth's] womb." She was "filled with the Holy Spirit," and in a loud voice she exclaimed to Mary, 'Blessed are you among women, and blessed is the child you will bear!'” (Fig. 3). Elizabeth congratulated Mary because the Lord had given her an extraordinary child [16]. Centuries earlier, the Lord had also blessed Hannah with a special child who had a special mission of service. When Hannah took Samuel to the Tabernacle to devote him to his sacred duty, she explained to the priest Eli, "I prayed for this child, and the Lord has granted me what I asked of him. So now I give him to the Lord ... [f] or his whole life" (1 Samuel 1:27-28). Likewise, Mary later took her son Jesus to the Temple in Jerusalem, "to present him to the Lord" and to consecrate him to the Lord's service (Luke 2:22-23). Hannah and Mary shared similar gifts, special children devoted to divine service.

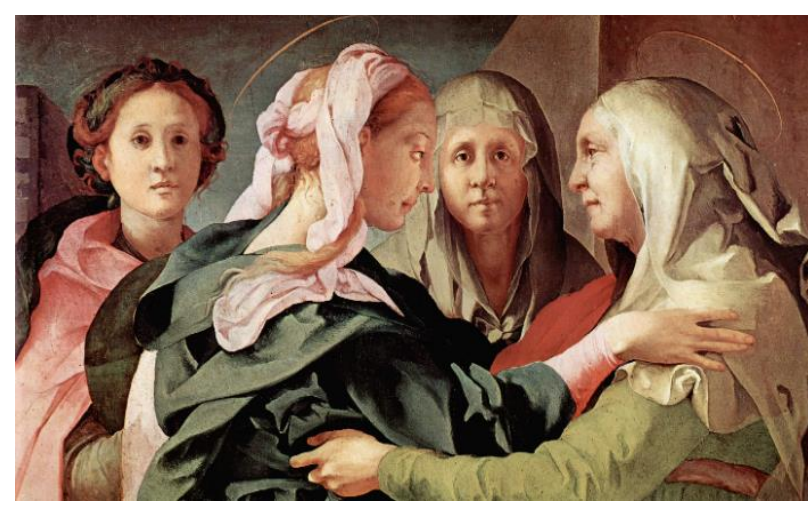

Fig. 3. Jacopo da Pontormo (1494-1556), Visitation of Mary, 1529, oil on canvas. Public Domain.

\section{B. The Magnificat}

Immediately after Elizabeth and Mary exchanged their greetings, Mary sang the Magnificat. The title comes from the Latin translation of the Greek word $\mu \varepsilon \gamma \alpha \lambda u$ v $\omega$ or megalynō, which in English means "magnifies" or "glorifies." In the early Latin Bible, the Biblia Sacra Vulgata (ca. A.D. 400), Mary's song begins "Magnificat anima mea Dominum." This was translated into English as "My soul doth magnify the Lord" (KJV) or "My soul glorifies the Lord" (NIV).

My soul glorifies the Lord and my spirit rejoices in God my Savior,

for he has been mindful

of the humble state of his servant.

From now on all generations will call me blessed, for the Mighty One has done great things for meholy is his name.

His mercy extends to those who fear him, from generation to generation.

He has performed mighty deeds with his arm; he has scattered those who are proud in their inmost thoughts.

He has brought down rulers from their thrones but has lifted up the humble.

He has filled the hungry with good things but has sent the rich away empty.

He has helped his servant Israel, remembering to be merciful to Abraham and his descendants forever, just as he promised our ancestors.

Hannah and Mary's songs follow a similar thematic order. Both begin with an introductory passage of praise that celebrates the great things "the Mighty One" has done specifically for the singer. Then, a prophetic section follows, describing how the Lord's mercy toward the humble has operated, and continues to operate, throughout history, from "the foundations of the earth," "from generation to generation." Finally, Mary concluded with an acknowledgment of the Lord's trustworthiness in fulfilling his covenants and in keeping his promises "forever." Hannah concluded with a prophetic warning that the Lord would eventually judge humanity through his exalted king.

Mary certainly knew Hannah's song; she even reused a few of Hannah's exact words.

\begin{abstract}
The Magnificat
1) My soul glorifies the Lord [and] rejoices

2) $[\mathrm{He}]$ scattered those who are proud.

3) $[\mathrm{He}]$ filled the hungry with good things.

4) $[\mathrm{He}]$ has lifted up the humble.

5) brought down rulers from their thrones
\end{abstract}

6) He has helped his servant.
Hannah's song

1) My heart rejoices in the Lord.

2) Do not keep talking so proudly.

3) $[\mathrm{T}]$ hose who were hungry are hungry no more.

4) [The Lord] humbles and he exalts.

5) [The needy will] inherit a throne of honor.

6) He will guard the feet of his faithful servants.

\section{Prophesizing from the Temple to the Home}

Both Hannah and Mary made prophetic utterances on similar topics, though in different historical contexts. Hannah prophesized the Lord would strengthen his king and exalt the horn of his anointed; Mary prophesized, "From now on all generations will call me blessed, for the Mighty One has done great things for me" (Luke 1:43). Luke was very purposeful in recording messianic prophesies in his account of the events surrounding the birth of Jesus. Luke recorded three such prophesies made by people connected to the Temple in Jerusalem: 1) Zechariah's Benedictus (Luke 1:5, 67-79); 2) Simeon's Nunc dimittis (Luke 2:25-35); and 3) the statement of Anna, who "never left the Temple" (Luke 2:36-38). Luke also recorded the angels' announcement Gloria in Excelsis (Luke 2:14). In form and content, these prophetic psalms and statements were "patterned on the "hymns of praise"" found in the book of Psalms. As such, they reflect the compositions of pre-Christian ... Jewish hymnology" [28], which included the song of Hannah. Prophesies recorded by Luke "are a medley of biblical imagery reconfigured into a new expression of exultant thanksgiving" [28]. In other words, in the New Testament Luke systematically documented contemporary prophesies of Jesus' messianic mission that relate directly back to Old Testament prophesies, including 


\section{that of Hannah.}

Note, however, that Mary and Elizabeth (Luke 1:42-45) prophesized in a home, in the Judean countryside outside Jerusalem. Sr. Monica Adigwe, of the Society of the Holy Child Jesus, has written about why this is significant. According to Sr. Adigwe, in the first chapter of Luke, Mary and Elizabeth "set in motion an irresistible chain of events, a firm paradigm of the proclamation of the word in the early church, which finds its matrix in the home" [29] (see also Acts $1: 13 ; 10: 25 ; 16: 15)$. Hannah sang her prophetic song in the central sanctuary, the Tabernacle, but Mary sang her prophetic song in a residence. The Tabernacle at Shiloh and the Temple in Jerusalem were the centers of worship in ancient Israel, but major early events of the Christian period often occurred in homes. Luke addressed his Gospel specifically to Theophilus, who was probably an upper-class Roman official. In all likelihood, though, Luke realized Theophilus would circulate his Gospel among "members of a Greek-speaking circle of Jewish-Christian[s]," who met in "house-churches" [28]. Jesus said wherever two or more of his disciples gathered in his name he would be present (Matthew 18:20). Hannah lived during the old covenant and sang in the Tabernacle; Mary lived during the establishment of the new covenant and sang the Magnificat in Elizabeth's home, a kind of house-church.

\section{The Scope of the Magnificat}

The Magnificat looks backward and forward. Mary sang of the Lord's past dealings with the nation of Israel, but she also rejoiced that his mercy would continue into the future "from generation to generation" (or from covenant to covenant). A major theme of the Gospel of Luke is God's continuous mercy, a freely given gift that will lift up the humble "both ancient and contemporary" [28]. Mary sang the Lord has brought down rulers; he has lifted the humble; he has sent the rich away empty; he has filled the empty. Mary used the present perfect tense, fusing the past with her present time. The Lord brought down rulers in the past and will continue to do so, the Lord lifted the humble in the past and he will continue to do so, etc. Given the context of her divine conception, Mary wished to emphasize that in the new Christian advent, the Lord's blessings would continue. Jesus expressed the same idea during his ministry, in the "Beatitudes," and when he said he did not "come to abolish the Law or the Prophets ... but to fulfill them" (Luke 6:2026; Matthew 5:3-10, 17).

Antiphonaries are liturgical books containing songs for use by Christian celebrants and choirs. In medieval antiphonaries Mary's song was often entitled Evangelium Marice, meaning the gospel (or "good news") of Mary [30]. The term gospel is associated with the descriptions of Jesus Christ's life and his teachings on eternal salvation that are found primarily in the New Testament books of Matthew, Mark, Luke, and John. In the Magnificat, though, Mary both displayed an impressive awareness of what God had done during the period of the Old Testament and she suggested what he would do during the nascent Christian epoch. According to historian Charles Herbermann, wide-ranging biblical thoughts and phrases so pervade the Magnificat - from Genesis, the psalms, and both the "major" and "minor" prophets-it sums up "in its inspired ecstasy the economy of God with His Chosen
People, and indicate[s] the fulfillment of the olden prophecy and prophesize[s] anew until the end of time" [30]. Mary's Magnificat "interweaves the narrative of Israel with the narrative of Jesus" [28]. Its impressive theological breadth and sophistication has led a small number of scholars to argue that Elizabeth (a more-experienced woman and the wife of a priest), rather than Mary, should be credited with the Magnificat, "but this idea has not persuaded the majority" [2].

\section{E. A Song, a Prayer, or a Poem?}

Although it has appeared in antiphonaries and songbooks for many centuries, historians have debated whether Mary chanted or sang the Magnificat (as a song), or perhaps spoke its words (as a communal prayer or poem) [30] (Fig. 4). Various Bible translations offer various titles, such as "Mary's Song" (NIV) or "Mary's Song of Praise: The Magnificat" (ESV). Most translations give no title at all. The scriptures do not say Mary sang the words. The oldest Greek manuscripts of Luke 1:46 contain the phrase "Mariam lego $(\lambda \varepsilon \dot{\varepsilon}(\omega)$, , which can be interpreted as "Mary said," or "Mary declared," or "Mary explained." The ancient manuscripts do not use the word hymneō ( $\dot{v} \mu v \varepsilon \dot{\varepsilon} \omega$ ), the Greek word translated as "sing a hymn" (as in Matthew 26:30). Similarly, even though some Bible translations give First Samuel 2:1-10 labels such as "Hannah's Song of Thanksgiving" (NASB), the ancient Hebrew scriptures state unambiguously, "hannâ

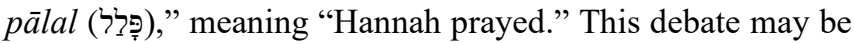
of little importance, though. Most Christians would probably agree that prayer, on a basic level, is a type of "union with God" concerned with petition, praise, and thanksgiving [11], which may be thought, spoken, chanted, or sung. Using this definition, both Hannah and Mary's songs qualify as prayers.

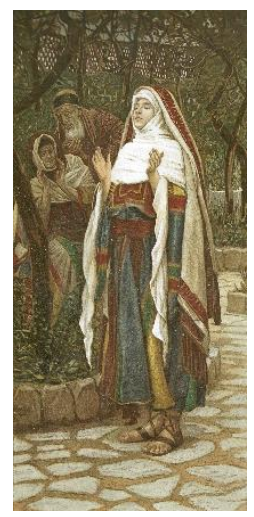

Fig. 4. James Tissot (1836-1902), Magnificat, 1894. Public Domain.

In English translations, Mary and Hannah's verb tenses vary slightly. Mary spoke of the Lord ("he has been mindful"), in the third person perspective. She did not speak directly to him, but, rather, she spoke about him. This could indicate Mary spoke, chanted, or sang aloud with the intent that other people would hear (in addition to God). Hannah, on the other hand, both spoke 1) of the Lord ("He will give strength") and 2) to the Lord ("I delight in your deliverance," "there is no one besides you"). Hannah used both the third person and second person perspectives. Hannah's words seem to blend the forms of songs and prayers. In contrast, in her brief inaudible prayer recorded in First Samuel 1:11, Hannah addressed the Lord exclusively in the second person perspective (“...if you will only look on your servant's 
misery...”).

\section{F. Humble Blessings, Prophetic Heights}

Whichever labels are attached to the Magnificat or Hannah's song, their words functioned as poetic prayers of praise and theological statements regarding the value of humbleness and God's mercy toward history's anawim. Anawim is a Hebrew word from the Old Testament describing vulnerable and marginalized people who remain faithful to God through difficult circumstances. The anawim are God's "faithful remnant" (see Psalm 37:9, 11; Matthew 5:3). Hannah and Mary both belonged to God's faithful remnant. The book of Psalms often speaks of the anawim, for example Psalm 9:18: "God will never forget the needy; the hope of the afflicted will never perish." In the Magnificat, Mary made use of such "traditional language" for her own purposes. When Mary said the Lord "has lifted up the humble" and "filled the hungry with good things" she spoke deliberately "so that [others heard] the echoes of the biblical tradition in the background" [2].

Both Mary and Hannah called attention to the significance of divine gifts. They each described the support faithful followers receive during desperate times. They each acknowledged that they were participating in a grand eternal plan. Both Mary and Hannah, however, placed their emphasis on the giver [God], rather than his gifts. They recognized that he is the "fountain" that leads to "the stream" of blessings for everyone [16]. This is why both Mary and Hannah began to see themselves not only as "humble servants" granted private gifts, but also as public witnesses of God's mercy. They were compelled to share their good news with the world, to share their blessings openly.

On Christmas Day 1864, Charles Spurgeon delivered a sermon at London's Metropolitan Tabernacle entitled "Mary's Song." Spurgeon emphasized Mary (and Elizabeth's) divine inspiration at the Visitation. He said, "Instead of two ordinary village women, we see before us two prophetesses and poetesses, upon whom the Spirit of God abundantly rested" [31]. Spurgeon said, "There was never a subject of sweeter song" than the imminent appearance of the "long-expected Messiah," the "stooping down of Godhead to the feebleness of manhood." Mary was delighted that through God's special grace the Messiah would be born of her. The Magnificat is a hymn of prophesy and a hymn of faith, because Mary sang of her belief in things unseen. Though her child was unborn, Mary remembered and believed the angel Gabriel's' words: "You have found favor with God. You will conceive and give birth to a son, and you are to call him Jesus. He will be great and will be called the Son of the Most High. ... [H] is kingdom will never end" (Luke 1: 30-33). As was the case with Hannah, divine inspiration carried Mary to poetic and prophetic heights. Filled with the Holy Spirit (Luke 1:35), Mary poised herself "upon the poetic wing," and looking down "the long aisles of the past, [she beheld] the mighty acts of Jehovah [throughout] the ages" [16], and she reflected on his mercy from past generations up to her own day.

\section{G. Foreshadowing and Messianic Prophesy}

Many Old Testament people and things foreshadowed New Testament people and things; sometimes this foreshadowing is conspicuous; sometimes it is subtle.
Hannah's song is subtle foreshadowing. A few of her phrases may seem elusive or general, but the blessing of an unexpected birth undoubtedly prompted Hannah's song (as with the Magnificat). The elevated content of Hannah's song and her soaring prose, though, showed she had greater inspiration and a grander purpose. The Scottish theologian, Patrick Fairbairn pointed out that, in a spiritual sense, Hannah sang her song during a time of "mournful barrenness and desolation in Israel ... [when] iniquity was rampant" [22], p. 139. According to Fairbairn, it was natural, therefore, that when her deepest wish had been divinely fulfilled, with Samuel's birth, and after she had devoted her child to God's service, Hannah felt "a prophetic impulse [and regarded] herself as specially raised up to be 'a sign and a wonder' to Israel." In her early verses, Hannah touched on "unfolding past and current events" and rejoiced in the Lord's delight in "exalting humble piety." Then, in her final verse, Hannah carried her narrative forward to the Messiah and his kingdom, to the coming "dispensation of Christ." Hannah concluded her song with "a sublime, glowing delineation of [Christ's eventual] righteous administration, [prophesizing] those who oppose the Lord will be broken. The Most High will thunder from heaven; the Lord will judge the ends of the earth. He will give strength to his king and exalt the horn of his anointed" [22], p. 140.

Fairbairn and other theologians believe Jesus has already fulfilled most of Hannah's prophesies. She prophesied the Lord would raise the poor to "a throne of honor," and the scriptures say Jesus now sits "at the right hand of the throne of God" (Hebrews 12:2), awaiting his faithful followers. Hannah prophesized the Lord would strengthen his king. The scriptures say this was fulfilled many times during the life of Jesus, including when Jesus prayed on the Mount of Olives and "an angel from heaven appeared to him and strengthened him" (Luke 22:43). Hannah prophesized the Lord has authority to "bring down to the grave and raise up," which Jesus demonstrated through his death, burial, and resurrection. Hannah also prophesized the Lord would "judge the ends of the earth," silence "the wicked ... in the place of darkness," and give the "faithful" a "throne of honor." Jesus reiterated this would occur at an uncertain time following his earthly ministry (Matthew 25:31-46).

Like Hannah's song, the Magnificat was a celebration sweeping over the Judeo-Christian faith. Mary's verses stretched from the covenant with Abraham, through Abraham's descendants, to the birth of Jesus, and into the Christian age. Like Hannah, Mary exulted the Lord's actions in the past, present, and future. Yet, a fundamental question remains. Why, as she was anticipating Jesus' birth, did Mary's thoughts and words so closely align with those of Hannah? Perhaps the answer is because Mary and Hannah shared the same inspiration. Luke wrote that Mary was filled with the Holy Spirit when she visited her cousin Elizabeth (Luke 1:35). The scriptures also say that Old Testament prophets like Hannah spoke through the inspiration of the Holy Spirit (see Psalm 143:10; 2 Samuel 23:2; Acts 28:25). Why would the Holy Spirit turn Mary's thoughts to the song of Hannah? Because by closely harmonizing Hannah and Mary's songs the Holy Spirit disclosed his "hidden design in the past" [22], p. 141; he disclosed that he had inspired Hannah's messianic prophetic utterances and that those 
utterances would be fulfilled by Mary's son, Jesus. Hannah's song heralded to people living under Mosaic Law that the new advent of the Messiah was coming [22], p. 141. Mary's Magnificat confirmed that the new advent had finally arrived. Through Hannah and Mary, the Holy Spirit forged a prophetic link between the old and new covenants.

Hannah prophesized the Lord would both "give strength to his king" and "exalt the horn of his anointed," and the New Testament scriptures show Jesus Christ also fulfilled these prophesies. During his ministry, Jesus traveled from town to town teaching in the Jewish synagogues, "The Spirit of the Lord is on me, because he has anointed me to proclaim good news to the poor" [emphasis added] (Luke 4:18). The Apostle Peter preached, "God anointed Jesus of Nazareth with the Holy Spirit and power, and ... God was with him" [emphasis added] (Acts 10:38). Anointing with oil was a traditional sign that someone had been chosen by God as a new prophet or a new king (1 Kings 1:39). Jesus and his followers explicitly taught that he was a new king (Matthew 2:2, 27:11; Mark 15:2; Luke 19:38, 23:3), though Jesus also explained his was not an earthly kingdom, but from "another place" (John 18:36). The New Testament scriptures also indicate God, the father, "exalted the horn" of Jesus, "his anointed." The book of Acts records the first gospel sermon of the Christian age, the Apostle Peter's message given on the day of Pentecost. Peter told his listeners that after Jesus was crucified and buried, God "raised this Jesus to life, and we are all witnesses of it. Exalted to the right hand of God, he has received from the Father the promised Holy Spirit and has poured out what you now see and hear" [emphasis added] (Acts 2:32-33). The word transliterated as "exalted" is the Greek word hypsoō or vं\%ó $\omega$, which means to elevate or exalt. It is equivalent to the Hebrew term used by Hannah in First Samuel 2:10 (וְירָם meaning to raise, lift high, or exalt. The Lord anointed Jesus as his king and exalted Jesus to a position of honor at his right hand, fulfilling Hannah's final prophesy

\section{CONCLUSION}

Neither Mary nor Luke explicitly stated that Hannah's song served as an historical "type" for the Magnificat. That omission, however, should not lead Bible students to overlook or minimize their relevant connections. Hannah and Mary shared an appreciation for the poetic songs of the Hebrew Bible, particularly the book of Psalms. Their songs contain identical themes and messages, at times conveyed with identical terms. Hannah and Mary shared the blessing of divinely ordained motherhood. They both expressed their gratitude for this blessing in prayerful songs, which addressed the Lord's broader mission and contained related prophetic utterances, inspired by the Holy Spirit. Hannah concluded her song with a declaration that the Lord would strengthen his anointed king and exalt his horn. Mary's song celebrated the pending birth of Jesus, who his followers recognize as a uniquely anointed and exalted spiritual king. The theological breadth and depth of their songs carries their significance beyond the limited, though extraordinary, contexts of Hannah and Mary's pregnancies and motherhoods. Indeed, the conclusion that the Holy Spirit used Hannah and Mary's songs as prophetic links, joining the old and new covenants of the Judeo-Christian faith is not only plausible, it is persuasive. For only in the life, death, resurrection, and ascension of Jesus Christ are both Hannah and Mary's messages fulfilled.

\section{REFERENCES}

[1] K. Keefe. (2021). Women's voices in the Bible: few but worth listening to. [Online]. Available: https://www.musicformass.blog/2017/12/09/mary-feasts-andwomens-voices/

[2] J. M. Smith. "I will sing to the Lord': Women's songs in the scriptures," Dialogue: A Journal of Mormon Thought, vol. 45(3), pp. 56-69, 2012. [Online]. Available: https://www.jstor.org/stable/10.5406/dialjmormthou.45.3.0056\#metad ata_info_tab_contents.

[3] M. S. Seale. "Deborah's ode and the ancient Arabian Qasida," Journal of Biblical Literature, 81(4), pp. 343-347, 1962.

[4] A. Devine. "Prophecy," in The Catholic Encyclopedia. New York Robert Appleton Company, 1911. [Online]. Available: http://www.newadvent.org/cathen/12473a.htm.

[5] J. Shepley. (2013). "Trembling on the verge of allegory." Historia Muthos, and Plasma. [Online]. Available: https://historiamuthosplasma.wordpress.com/2013/05/30/jacob-havei-loved-but-esau-have-i-hated-the-distinction-between-typology-andallegory-in-the-modern-study-of-exegesis/.

[6] W. Gage. (2010). "Types and shadows," Ligonier Ministries. [Online]. Available: https://www.ligonier.org/learn/devotionals/types-andshadows/.

[7] T. Fuhrer. "Allegorical reading and writing in Augustine's Confessions," in 'In Search of Truth': Augustine, Manichaeism and other Gnosticism. Leiden: Brill, 2010, pp. 25-46.

[8] M. R. Gulley, Systematic Theology: Prolegomena, vol. 1. Berrien Springs, MI: Andrews University Press, 2003.

[9] The Commission on Theology and Church Relations. (1996) "Prophecy and typology." The Lutheran Church-Missouri Synod. [Online]. Available: https://files.lcms.org/wl/?id=fHXqqwCUzdcDWmR60rOqfD0wJDU mmTWT.

[10] J. Smart, The Interpretation of Scripture. Philadelphia: Westminster, 1961.

[11] J. Wynne. "Prayer," in The Catholic Encyclopedia. New York: Robert Appleton Company, 1911. [Online]. Available: http://www.newadvent.org/cathen/12345b.htm.

[12] S. O. Ademiluka, "Interpreting the Hannah narrative (1 Sm 1:1-20) in light of the attitude of the church in Nigeria towards childlessness," Verbum Eccles, vol. 40(1), n. p., 2019.

[13] J. S. Baden, "The nature of barrenness in the Hebrew Bible, in Disability Studies and Biblical Literature, C. R. Moss \& J. Schipper, Ed. New York: Palgrave Macmillan, 2007.

[14] C. R. Chapman. (2021). Barrenness. Bible Odyssey. [Online] Available: https:/www.bibleodyssey.org:443/en/people/relatedarticles/barrenness.

[15] C. Spurgeon. (2017 reprint). A woman of a sorrowful spirit, Collection: Metropolitan Tabernacle Pulpit, vol. 26. [Online]. Available: https://www.spurgeon.org/resource-library/sermons/a-woman-of-asorrowful-spirit/\#flipbook/.

[16] M. Henry. (2021 ed. of 1610 original). Matthew Henry Commentary on the Bible. [Online]. Available: https://www.biblestudytools.com/commentaries/matthew-henrycomplete/.

[17] L. L. Bronner, "Hannah's prayer: Rabbinic ambivalence," Shofar, Vol. 17(2), pp. 36-48, 1999

[18] Y. Hurwitz, "On the Haftarah: The power of Chana's prayer," Chabad, 2021. [Online]. Available: https://www.chabad.org/parshah/article_cdo/aid/3449362/jewish/Onthe-Haftarah-The-Power-of-Chanas-Prayer.htm.

[19] T. M. Cohn, Baal Shem Tov Heart of Prayer. New York: BST Publishing, 2010.

[20] Jean \& Alexander Heard Libraries. (2021). Art in the Christian Tradition. Vanderbilt University. [Online]. Available: http://diglib.library.vanderbilt.edu/act-imagelink.pl?RC=54184.

[21] S. Corbitt.. "The 'Magnificat gift' of Advent." Public Discourse: The Journal of the Witherspoon Institute: n.p. (2020, December 20).

[22] P. Fairbairn, The Typology of Scripture, vol. I \& II. Edinburgh: T. \& T Clark, 1864.

[23] Period of Judges. (2021). Encyclopedia of the Bible. Bible Gateway. [Online]. 
https://www.biblegaZteway.com/resources/encyclopedia-of-thebible/Period-Judges.

[24] J. W. Watts. "Song and the ancient reader," Perspectives in Religious Studies, vol. 22(2), pp. 135-147, 1995.

[25] J. Goldingay, Psalms: Volume 1: Psalms 1-41. Grand Rapids: Baker Academic Press, 2006

[26] J. McKinnon, Music in Early Christian Literature. Cambridge: Cambridge University Press, 1987.

[27] S. Salaville. "Hebron," in The Catholic Encyclopedia. New York: Robert Appleton Company, 1910. [Online]. Available: http://www.newadvent.org/cathen/07184a.htm.

[28] D. W. Casey. (2000). Mary's Magnificat: "My soul magnifies the Lord and my spirit rejoices." Scripture from Scratch. [Online]. Available: https://web.archive.org/web/20121220121803/http:/www.americancat holic.org/Newsletters/SFS/an1200.asp.

[29] M. Adigwe. (2021). Reflection on the Visitation of Mary. Society of the Holy Child Jesus. [Online]. Available: https://www.shcj.org/reflectionon-the-visitation-of-mary/.

[30] H. Henry. "Magnificat," in The Catholic Encyclopaedia. New York: Robert Appleton Company, 1910. [Online]. Available: http://www.newadvent.org/cathen/09534a.htm.

[31] C. Spurgeon. (2017 reprint). Mary's song. Collection: Metropolitan Tabernacle Pulpit, vol. 10. [Online]. Available: https://www.spurgeon.org/resource-library/sermons/maryssong/\#flipbook/.

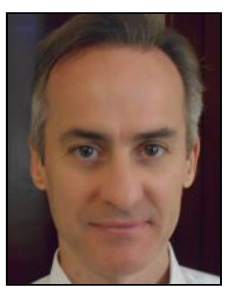

James W. Ellis earned his J.D. degree at the Benjamin N. Cardozo School of Law, Yeshiva University, New York, NY, USA (2006, jurisprudence), his $\mathrm{Ph} . \mathrm{D}$. at Case Western Reserve University, Cleveland, OH, USA (2003, art history), his M.A. at Rice University, Houston, TX, USA (1999, art history), and his B.A. at the University of Houston, Houston, TX, USA (1997, art history).

$\mathrm{He}$ is currently a freelance writer and scholar, based in Hong Kong. He has taught at Hong Kong Baptist University, City University of Hong Kong, and Cleveland State University. His articles have appeared in Mission Studies, Asia Journal of Theology, Global Missiology, Journal of Religion and Society, and other publications. He is the author of Psalms, Hymns, and Spiritual Songs: The Musical Heritage of the Churches of Christ (Seattle: Amazon Publishing, 2019). He has presented his research at conferences in Hong Kong, Japan, Switzerland, the USA, and Canada.

Dr. Ellis' research focuses on religious history, cultural history, and the fine arts. 